\title{
The Role of Judicial Interpretation in the "Competition" of Commercial Courts in Russia
}

\author{
Aidys S. Tykyl-ool* \\ Tuvan State University \\ 36 Lenin Str., Kyzyl, Republic Tuva, 667000, Russia
}

Received 15.03.2018, received in revised form 28.05.2018, accepted 05.06.2018

The purpose of the article is to discover the role of judicial interpretation of legal norms in dispute resolution based on the concept of opportunity costs, as well as to establish the existence of "competition" of Russian commercial courts.

The concept of opportunity costs is essentially related to the process of choice. Opportunity costs exist when there are at least two courses of action, and the decision maker can select either course of action as his/her own choice. The value of the rejected choice is the opportunity cost of the choice.

Interpretation of legal norms recognizes a set of techniques used to understand the essence of legal norms. In the opinion of the author, "competition" of commercial courts of Russia is a rivalry between legal opinions of judicial bodies based on interpretation of Russian legislation.

The author conducted an economic and legal analysis of influence of judicial interpretation on the behavior of business and, thus, discovered "competition" between Russian commercial courts.

Keywords: interpretation, economic analysis of law, jurisdiction, commercial courts, competition.

DOI: 10.17516/1997-1370-0290.

Research area: law.

\section{Statement of the problem}

The present article, for the first time in the Russian legal science, considers the role of judicial interpretation and the discretion of judges in disputes resolution from the viewpoint of the opportunity cost theory, as well as discloses the possibility of "competition" of Russian commercial courts in the business environment.

If the category "competition of jurisdictions" (it is widely known that large corporations prefer to structure mergers and acquisitions transactions following English, but not Russian law) has long become a part of business practice and legal doctrine, the notion of the "competition" of courts requires clarification.

The author of the present article sees "competition" of courts as a rivalry between legal opinions (approaches) of specific judicial bodies arising as a result of interpretation of the norms of different branches of Russian legislation by courts when considering disputes. However, the fact that judges do not aim to such rivalry in the process of justice administration should be taken into account. Such "competition" of courts arises

(C) Siberian Federal University. All rights reserved

* Corresponding author E-mail address: aidys@yandex.ru 
due to the established (consistent) or formed, as a result of the interpretation of the norms of law, judicial practice in a specific commercial court (first instance court, the court of appeal or commercial court of a district).

Along with the practical inapplicability of the institute for judge rejection in Russia, an important role in the "competition" of courts is played by judicial interpretation which is reflected in judicial acts containing certain legal proposition (approaches).

In Russian legal thought, interpretation is a set of techniques used to understand and clarify legal norms.

The norms of law need interpretation, firstly, because of their practical importance and, secondly, because of law provision ${ }^{1}$.

Thus, in case of judicial acts appeal, higher courts verify the correctness of application and (or) interpretation of substantive law and (or) procedural law norms by commercial courts that considered the case (Part 2, Article 291.14 and Part 2, Article 308.11 of the Arbitration Procedural Code of the Russian Federation ${ }^{2}$ (hereinafter - APC RF).

At the same time, the instructions of the Higher Commercial Court, including the interpretation of law stated in its act, are mandatory for the commercial court that considers the case again (Part 2, Article 289, Part 4, Article 291.14, Part 5, Article 308.11 of the APC RF).

In addition, commercial courts judges are independent in the administration of justice, they are affected only by the Constitution of the Russian Federation and the federal law (Part 1, Article 120 of the Constitution of the Russian Federation ${ }^{3}$, Part 1, Article 5 of the APC RF).

This article presents the economic and legal analysis of the mechanism of the influence of judicial interpretation of law to economic entities conduct and, in this connection, to the emergence of "competition" between Russian commercial courts.

\section{Normative prerequisites \\ for the "competition" \\ of commercial courts}

According to Part 3, Article 4 of the Federal Constitutional Law of December 31, 1996 No. 1-FKL "On the Judicial System of the Russian Federation"4 (hereinafter FKL on the Judicial System), the federal judicial system of Russia ${ }^{5}$ consists of the Constitutional Court of the Russian Federation, the Supreme Court of the Russian Federation, courts of general jurisdiction and commercial courts.

The procedural law of the Russian Federation establishes jurisdiction and cognizance of cases. Corporate disputes, in particular, are considered only in commercial courts (Part 1, Article 33, Article 225.1 of the APC RF).

The general rule of jurisdiction of commercial courts lies in the fact that a lawsuit is brought at the defendant' place of location or residence (Article 35 of the APC RF).

Meanwhile, Article 35 of the APC RF establishes an opportunity to choose the jurisdiction for the plaintiff. Thus, according to Part 2 of the aforementioned article, a suit against defendants located or residing in the territories of different subjects of the Russian Federation is brought to the commercial court according to the location or residence of one of the defendants. The claim arising from the contract, where the place of its execution is indicated, can also be brought to the commercial court at the place of the contract execution (Part 3 of Article 35 of the APC RF).

In addition, Article 37 of the APC RF allows to establish contractual jurisdiction: jurisdiction, established by Articles 35 and 36 of the APC RF may be amended by the agreement of the parties before the commercial court accepts a lawsuit for its hearing. It should be noted that according to Article 38 of the APC RF there is no possibility to apply different rules of jurisdiction for a certain 
category of cases than those established by this norm, including changing jurisdiction by the agreement of the parties (Decree of the Presidium of the Supreme Arbitration Court of the Russian Federation No. 14307/06 No. A55-12796/2005 of April 23, 2007).

According to the opinion of the author of the present article, the choice of jurisdiction by entrepreneurs can be explained by the opportunity costs theory.

\section{Opportunity Costs Theory}

The concept of opportunity costs was first introduced by the Scottish economist Adam Smith in the $18^{\text {th }}$ century and further developed in the works of Friedrich von Wieser, Alfred Marshall, et al ${ }^{6}$.

The opportunity costs theory is inextricably linked to the decision-making process. Opportunity costs exist in the case when it is necessary to choose one out of two or more variants of behavior, and the decision-maker can choose an appropriate option at his/her own discretion. The value and benefits of the variant of behavior, which a person, who made the decision, refused, are the opportunity costs of such a choice (decision) ${ }^{7}$.

The opportunity costs theory has also been reflected in legal practice. Lawyers, in particular, may choose to file a claim for the advance payment recovery under a sales contract, for example, instead of making a settlement agreement that was offered by the counterparty. The property that the counterparty wanted to offer as a compensation will be the opportunity cost in this case. How do the opportunity costs affect the choice of jurisdiction?

\section{The concept of opportunity costs \\ in the selection of jurisdiction}

Business unit calculates opportunity costs, including practice reflecting courts approaches to the interpretation of different legal issues, mostly concerning essential property interests. Opportunity costs calculation is a consequence of the existence of opposing legal positions on one legal issue, in other words - the consequence of the "competition" of commercial courts in the interpretation of the norms of law.

The choice of jurisdiction determined by the "competition" of commercial courts may arise:

1) at the stage of making a contract - the parties may be guided by the practice of specific issues interpretation in the corresponding courts when opposite legal positions are applied in different courts; the competition can be recorded in determining contractual jurisdiction;

2) at the stage of a dispute arising, an artificial change of jurisdiction, which will be discussed below, or establishment of contractual jurisdiction by the parties in a case, may be applied.

The presence of the courts' opposing approaches can be demonstrated in practice through astreinte recovery (a sum of money for non-execution of a judicial act):

1. Astreinte is not applicable to the cases of non-fulfillment of financial obligations: see, for example, Resolution of the Plenum of the Supreme Court of the Russian Federation of March 24, 2016 No. 7 "On Court Application of Certain Provisions of the Civil Code of the Russian Federation Regarding Liability for Breach of Obligations"; Resolution of the Moscow Commercial Court of March 4, 2016, case No. A40-239030/15-26-546; Resolution of the Commercial Court of the Sverdlovsk Region of March 15, 2016, case No. A60408/2016; Resolution of the Commercial Court of Moscow Region of March 2, 2016, case No. A41-99318/15; Resolution of the Commercial Court of Samara Region of February 19, 2016, case No. A55-24022/2015; Resolution of the Commercial Court of the City of St. Petersburg 
and Leningrad Region of March 10, 2016, case No. A56-77973/2015.

According to this approach, under Article 308.3 of the Civil Code of the Russian Federation, astreinte is applied at the creditor's request only in relation to judicial acts in specific performance, unless otherwise provided by laws or the terms of contract or does not follow from the nature of the obligation.

At the creditor' request the court has the right to award a sum of money in his/her behalf (Part 1, Article 330 of the Civil Code of the Russian Federation) in the event of non-enforcement of the specified judicial act in the amount determined by the court based on the principles of justice, proportionality and inadmissibility to gain an advantage as the result of unlawful or unfair conduct (Part 4, Article 1 of the Civil Code of the Russian Federation).

Thus, the effect of the norm of Article 308.3 of the Civil Code of the Russian Federation is aimed only at a situation when the debtor did not fulfill the resolution the subject of which was the defendant's obligation for specific performance.

2. Astreinte can be applied to financial obligations: see, for example, Resolution of the Moscow Commercial Court of February 12, 2016, case No. A40-214483/15-83-1796.

This approach contradicts part 30 of the Resolution of the Plenum of the Supreme Court of the Russian Federation of March 24, 2016 No. 7 that astreinte is not applied for non-execution of financial obligations and, in this connection, judicial acts adopted in contradiction with the explanation of the Plenum of the Supreme Court of the Russian Federation can be reviewed in accordance with Article 311 of the APC RF.

Based on the example of astreinte recovery practice, it is possible to assume that entrepreneurs will establish contractual jurisdiction in the court that allows astreinte recovery for financial obligations.
It should be noted that civil circulation participants often challenge contractual jurisdiction, for instance, when the parties established it with respect to the disputes related to real estate, thereby violating exclusive jurisdiction (Resolution of the Commercial Court of the West-Siberian District of August 07, 2014, case No. A70-11571/2013).

In addition, various methods aimed at artificial change of jurisdiction, including through the abuse of law, are used in legal practice:

1) bringing an improper co-defendant to create rules for alternative jurisdiction under Part 2 of Article 36 of the APC RF (the so-called "false complicity"), since the case adopted by the court in compliance with the rules of jurisdiction must be considered on the merits, even if it becomes within jurisdiction of another court in the future (Part 1, Article 39 of the APC RF). However, if in the process of case consideration, it is established that it was adopted with the violation of the rules of jurisdiction, then under Part 2 of Article 39 of the APC RF, the court transfers the case to another court of the same level;

2) making surety contracts with a person whose location is beneficial for the plaintiff for the subsequent law enforcement provided by Part 2 of Article 36 of the APC RF.

This method is limited by the explanations of Part 5 of the Resolution of the Plenum of the Supreme Arbitration Court of the Russian Federation of 12.07.2012 No. 42 "On Some Issues of Disputes Resolution Related to Surety", whereby in case of establishing the fact of the coordinated actions of the creditor and the guarantor, aimed at making a surety contract in defiance of the debtor's desire and capable of causing such unfavorable consequences for the debtor as a change in the dispute jurisdiction, transfer of the rights of claim against the debtor to the guarantor, despite the prohibition of assignment of claim without the debtor's consent 
stipulated in the principal obligation, etc., the court may apply Article 10 of the Civil Code of the Russian Federation (to recognize these actions as abuse of law and to refuse judicial protection).

3) the "transfer" of the case to exclusive jurisdiction (the plaintiff, for instance, can combine the requirements with the requirement related to the right to immovable property (Part 7, Article 36 of the APC RF);

4) at the stage of making a contract a party may implicitly insist on choosing a beneficial, from a procedural point of view, place of performing obligation (Article 316 of the Civil Code of the Russian Federation, Part 4 of Article 36 of the APC RF).
All the above-mentioned legally significant procedural actions are aimed at making balanced decisions by the entrepreneurs taking into account opportunity costs.

\section{Conclusion}

The opportunity costs theory gave an opportunity to demonstrate the economic essence of entrepreneurs' behavior when choosing jurisdiction, as well as to reveal the existence of "competition" between commercial courts of Russia. In this regard, the author of the present article makes a conclusion about practical applicability and relevance of the method of economic analysis of law.

\footnotetext{
$1 \quad$ Vas'kovskii, E.V. (2002). Tsivilisticheskaia metodologia: Uchenie o tolkovanii i priminenii grazhdanskikh mekhanizmov [Civilistic Methodology: The Doctrine of the Interpretation and Application of Civil Mechanisms]. Moscow, 2002, p. 81. Collected Acts of the Russian Federation, 29.07.2002, No. 30, Article 3012.

Collected Acts of the Russian Federation, 04.08.2014, No. 31, Article 4398. Collected Acts of the Russian Federation, 06.01.1997, No. 1, Article 1.

The courts of the subjects of the Russian Federation operate in Russia as well.

Yip, David S.O. (1999). A Critical Review of the Opportunity Cost Concept. PhD thesis. London School of Economics and Political Science, pp. 12-13.

Ibid., p. 10.
}

\section{References}

Commercial Procedure Code of the Russian Federation, In Collected Acts of the Russian Federation, 29.07.2002, No. 30, Article 3012.

Resolution of the Plenum of the Supreme Arbitration Court of the Russian Federation of July 12, 2012, No. 42 "On Some Issues of Disputes Resolution Related to Surety".

Resolution of the Plenum of the Supreme Court of the Russian Federation of March 24, 2016, No. 7 "On Court Application of Certain Provisions of the Civil Code of the Russian Federation Regarding Liability for Breach of Obligations".

Resolution of the Commercial Court of the West-Siberian District of August 07, 2014, case No. A70-11571/2013.

Resolution of the Moscow Commercial Court of March 4, 2016, case No. A40-239030/15-26-546. Resolution of the Commercial Court of Sverdlovsk Region of March 15, 2016, case No. A60-408/2016.

Resolution of the Commercial Court of Moscow Region of March 2, 2016, case No. A41-99318/15.

Resolution of the Commercial Court of Samara Region of February 19, 2016, case No. A55$24022 / 2015$.

Resolution of the Commercial Court of the City of St. Petersburg and Leningrad Region of March 10, 2016, case No. A56-77973/2015.

Resolution of the Moscow Commercial Court of February 12, 2016, case No. A40-214483/15-83-1796.

The Federal Constitutional Law of 31.12.1996 No. 1-FKL "On Judicial System of the Russian Federation”, In Collected Acts of the Russian Federation, 06.01.1997, No. 1, Article 1. 
The Constitution of the Russian Federation, In Collected Acts of the Russian Federation, 04.08.2014, No. 31, Article 4398.

Vas'kovskii, E.V. (2002). Tsivilisticheskaia metodologia: Uchenie o tolkovanii $i$ priminenii grazhdanskikh mekhanizmov [Civilistic Methodology: The Doctrine of the Interpretation and Application of Civil Mechanisms]. Moscow.

Yip, David, S.O. (1999). A Critical Review of the Opportunity Cost Concept. PhD thesis, London School of Economics and Political Science.

\title{
Роль судебного толкования \\ в «конкуренции» арбитражных судов России
}

\author{
А.С. Тыкыл-оол \\ Тувинский государственный университет \\ Россия, 667000, Республика Тьвва, \\ Кьззыл, ул. Ленина, 36
}

\begin{abstract}
Цель статьи - раскрытие роли толкования норм судами при разрешении экономических споров с точки зрения теории альтернативных издержек, а также установление наличия «конкурениии» арбитражных судов России.

Теория альтернативных издержек неразрывно связана с прочессом принятия решений. Альтернативные издержски существуют, когда необходимо выбрать один из двух или более вариантов поведения, и лицо, принимающее решение, может выбрать соответствующий вариант по своему усмотрению. Ценность и блага того варианта поведения, от которого лицо, принявшее решение, отказалось, являются альтернативныли издержками такого выбора (принятия решения).

Толкованием норм признается совокупность приемов, применяемых для понимания и уяснения правовых норм. Под «конкуренцией» арбитражных судов России автор понимает соперничество правовых позиций (подходов) конкретных судебных органов, возникающее в результате толкования судами норм разных отраслей законодательства России при рассмотрении споров.

На основе теории альтернативных издержек автором проведен экономико-правовой анализ механизма влияния судебного толкования норм на поведение экономических субъектов и сделан вывод о наличии «конкуренции» между арбитражными судами России.
\end{abstract}

Ключевые слова: толкование, экономический анализ права, подсудность, арбитражные суды, конкуренция.

Научная специиальность: 12.00.00 - юридические науки. 